\title{
An Introduction to Forest Governance, People and REDD+ in Latin America: Obstacles and Opportunities
}

\author{
Anne M. Larson ${ }^{1, *}$ and Elena Petkova ${ }^{2}$ \\ 1 Center for International Forestry Research, Aptdo J-148, Managua, Nicaragua \\ 2 Jalan Cifor, Situ Gede, Center for International Forestry Research, Bogor, 16115, Indonesia; \\ E-Mail: e.petkova@cgiar.org \\ * Author to whom correspondence should be addressed; E-Mail: a.larson @ cgiar.org; \\ Tel.: +505-2265-7157.
}

Received: 21 October 2010 / Accepted: 4 January 2011 / Published: 19 January 2011

\begin{abstract}
REDD+ is a potentially significant financial mechanism for shifting the incentives from deforestation and land use change to forest conservation and sustainability. Even though REDD+ is not primarily a governance reform, it will affect or be affected by forest governance, it can improve forest governance or be undermined by its failures and, therefore, it depends on good forest governance if it is to be efficient, effective and equitable. This article provides an overview of key issues in forest governance in Latin America and discusses the risk and opportunities for REDD+. Though progress has been made in some areas, there is still much to be done, and REDD+ could reinforce or be undermined by problematic governance tendencies that affect its effectiveness, ability to decrease carbon emissions, and/or its legitimacy. The article recommends priority investments in institutional capacity, inter-institutional negotiation mechanisms, citizen participation and safeguards for forest-based populations.
\end{abstract}

Keywords: climate change; forest-based communities; REDD+; forest governance; Latin America

\section{Introduction}

The concept of governance, and particularly good governance, has become an important factor in international development discourse since the late 1980s, including discourse regarding forests. Reducing Emissions from Deforestation and Forest Degradation, now commonly known as REDD+, is 
a potentially significant financial mechanism for shifting the incentives from deforestation and land use change to forest conservation and sustainability. REDD is defined in the Bali Action Plan, par. 1(b)(iii), as: 'Policy approaches and positive incentives on issues relating to reducing emissions from deforestation and forest degradation in developing countries; and the role of conservation, sustainable management of forests and enhancement of forest carbon stocks in developing countries.' It is therefore an important step towards reducing emissions from land use change, delivering at the same time co-benefits such as biodiversity conservation and poverty alleviation. Even though REDD+ is not primarily a governance reform, it will affect or be affected by forest governance, it can improve forest governance or be undermined by its failures and, therefore, it depends on good forest governance if it is to be efficient, effective and equitable.

Governance has a variety of meanings, and what is 'good' is susceptible to wide interpretation. In some definitions, governance refers primarily to government; in others, to relations between the state and society [1, see also 2]. The World Bank defines governance as 'the traditions and institutions by which authority in a country is exercised'; legality, legitimacy and participation are key attributes of the rules and processes associated with governance [3-5]. In this article we take a broader definition: Governance refers to who makes decisions and how decisions are made, from national to local scale, including formal and informal institutions and rules, power relations and practices of decision making [6-9]. It also refers to the kinds of decisions that are made and whether they are clear, consistent and comprehensive [10]. Hence good forest governance means decisions are fair, transparent and just, rights are respected, laws and rules are enforced equitably, decision makers are accountable, and decisions are made based on the analysis of what is good for people and forests in general and not personal interest.

The main objective of good forest governance is to ensure forest sustainability, together with fair decision making and benefit distribution. But ecological, economic and social sustainability cannot be achieved through good forest governance alone. For example, if agricultural uses of forests provide higher economic returns, efficient markets may still drive deforestation [11]. Attention only to market efficiency and effectiveness will also fail to achieve resource sustainability. That is, good forest governance alone does not inherently address the drivers of deforestation and degradation. The right kinds of governance reforms across various sectors affecting forests could, however.

Latin American forests are critical for reducing carbon emissions and already attract significant attention in the context of REDD+ (e.g., Norway-Brazil, U.S.-Mexico). REDD+ presents an opportunity to provide the missing economic link, shifting incentives for deforestation and degradation and improving forest governance and sustainability. But REDD+ also risks being shaped by —rather than transforming - existing governance deficiencies. REDD+ funds could line the pockets of a few individuals, place additional burdens on the rural poor and/or fail to diminish carbon emissions. If it is going to succeed, then, finding the practical ways in which forest governance can be improved is top priority. And given the number and diversity of people that depend on and use forests in Latin America, as well as those who convert them to other uses, REDD+ will not succeed without addressing these issues. What are the main governance challenges REDD+ faces? What key governance reforms are needed to ensure its success?

This article provides an overview of forest governance in Latin America, with particular emphasis on challenges in light of REDD+, as an introduction to this special issue of Forests. Though REDD+ is 
partly being designed through a global governance mechanism, this article focuses mainly on governance issues at the national scale. The next section presents a snapshot of Latin America's forests, forest peoples and climate change. Section 3 provides a brief summary of the historical, political and economic roots of current trends and challenges in forest governance in the region. Sections 4 to 10 discuss the central issues in forest governance today as they affect forests and the people who depend on them and the risks and opportunities in relation to REDD+. Section 11 provides a synthesis of the governance reforms needed to ensure the success of REDD+ initiatives and is followed by the conclusions.

\section{Latin American Forests, Forest Peoples and Climate Change}

The Latin America and Caribbean (LAC) region harbours about 23\% of the world's forests [12]. Of that 23\%, 90\% is in South America and 7\% in Mexico; Brazil alone accounts for 52\% of the region's forest (and 12\% of the world's total). Forest cover declined from 1011 million hectares in 1990 to 964 million in 2000 [13], and to 924 million ha in 2005 [12]. The deforestation rate from 1990 to 2000, at about 4.28 million ha per year, was somewhat lower than the global annual net loss, of 5.11 million ha [14], but rose to 4.7 million annually from 2000 to 2005 [12,15]. Between 2000 and 2005, LAC accounted for $65 \%$ of global net loss of forest cover, with $1.2 \%$ annual loss in Central America, $0.5 \%$ annual loss in South America and a net gain of 0.9\% in the Caribbean [12]. Though percent losses were higher in Central America, total deforestation was much greater in South America, where rural population densities are still much lower and land availability is greater. [For more on differences between the two regions, see 16]

Globally over one billion rural people depend on forests to some extent for their livelihoods, the majority of them extremely poor [3]. Latin America's rural population is very poor. According to the Economic Commission on Latin America, which assesses poverty in relation to the cost of a 'basic basket' of goods and services in each county context, $78 \%$ of the rural population was poor and $47 \%$ extremely poor in 1997, higher percentages than in 1980 in spite of economic growth in the region [17]. Though reliable data is hard to find since most national poverty statistics do not separate rural forestbased from non forest-based populations, there is wide recognition that deep rural poverty and the remaining natural forests tend to overlap [18]. For example, two maps, one from Central America by the Center for the Support of Native Lands [19] and one of the Amazon by the Red Amazónica de Información Socioambiental Georeferenciada [20], demonstrate the overlap between natural forest and indigenous peoples and territories. Though indigenous people are not the only forest-based populations, they are the poorest: Being indigenous increases the likelihood of being poor by 13 times [21]. Other forest-based groups include agroextractive people, smallholder colonists, landless people, informal loggers and medium- and large-scale landowners, all with diverse interests in forests.

Forests have great significance at different scales for a variety of goods and services. Carbon and biodiversity conservation are valued globally, but LAC forests also contribute $13 \%$ of global industrial roundwood, $10 \%$ of sawn wood and $8 \%$ of wood pulp production [15]. Nationally, forests contribute to GDP and jobs as well as a variety of goods and ecosystem services. According to data from the Food and Agriculture Organization (FAO) [22], the GDP contribution of forests in the LAC region was $1.9 \%$ in 2006, almost double the world average of $1 \%$, and the forest sector accounted for $0.7 \%$ of total 
employment (about 1.5 million jobs), particularly in logging, wood products and pulp and paper [15]. Actual contributions are higher than these figures demonstrate, however, because national accounts fail to include the informal sector or the positive externalities of forests [15]. Even small contributions can be significant for local livelihoods. For example, an analysis of a national rural survey in Mexico demonstrated that natural resource income, though relatively small, played a significant role in reducing poverty and inequality [23]. At local or landscape scales, forests also provide important ecosystem services and, for many communities, may represent historical, cultural and spiritual values.

The effects of global climate change have already been felt in the region and are likely to affect forests further. According to the Intergovernmental Panel on Climate Change, observed effects include climatic variability and an increase in extreme events, as well as important changes in precipitation and some increases in temperature [13]. Under future change scenarios for three time-scales (2020, 2040 and 2080), temperatures in the region are expected to increase between 1 and 6 degrees $\mathrm{C}$, millions of people will experience water stress and 'significant species extinctions' are predicted. Savannas are expected to replace tropical forests in the eastern Amazon and central and southern Mexico [13,15]. The potential result is a downward spiral of decreased forest cover, declining rainfall, higher temperatures and dryer conditions and an increased risk of fires [15].

Land use changes have exacerbated degradation. Latin America is responsible for $4.3 \%$ of global greenhouse gas (GHG) emissions, almost half of which, according to some studies in the region, result from deforestation [13]. In the Amazon basin and parts of Central America, the main driver of deforestation is the expansion of capital-intensive agriculture and cattle ranching; in dryer and more populated regions, the main drivers are forest fires and population pressure [24]. In 2005, the FAO predicted that 18 million ha of forest in South America and 1.2 million ha in Central America would be converted to pasture and livestock production by 2010 [13].

At the local level, forests support the livelihoods of the most vulnerable populations. At the national level, they contribute to jobs, GDP and development; they provide ecosystem services and maintain temperatures that are important irrespective of the forests' location. And at the global level, their value for controlling GHG emissions is critical. These considerable pressures on Latin American forests and their value at multiple scales present a serious challenge for forest governance and highlight the need for solutions.

\section{The Roots of Current Governance Conditions}

Forest governance arrangements determine how the central questions regarding forests, livelihoods and sustainability have been answered to date-and how they will be answered under REDD+ schemes. These questions include which forests should be used for what and by whom, and what strategies will be adopted, if any, to stop or slow deforestation and forest degradation and to enhance carbon stocks. Institutional relationships, policies and development patterns with deep historical roots shape current decision making practices. These, together with existing pressures and demands on forests, will influence REDD+ in Latin America and determine its ability to effectively reduce carbon emissions.

The current conditions and challenges in forest governance have emerged from a history of policies and practices that have shaped the political and economic relationship between the state and both 
forests and forest peoples. Whilst governance has made important progress in some respects, challenges are embedded in a set of structural problems that cannot be easily solved, including low education levels, poverty and clientelism, but fundamentally decisions over forests have depended primarily on the relative power of the respective interest group and the economic rather than the environmental benefit. Meaningful policy reforms have had positive impacts in some cases, but there is important room for further progress. This section examines the historical evolution of forest governance in Latin America and the roots of the key problems it faces today.

In the past century, Latin America's forests have had much lower population pressures than much of Asia and Africa, and economic development has been primarily based on other natural resources, particularly agriculture, mining and petroleum. Forests were useful sources of an apparently endless supply of timber, but primary interest was in other resources such as rubber during periods of high demand and subsoil resources like minerals and petroleum. Production in these areas generally revolved around enclaves that did not often lead to long-term development or even permanent settlements.

Forests were mostly important as a supply of land. As in many other parts of the world, into the late 20th century, much of Latin America's forests were seen as unproductive lands available for the taking. For example, as recently as 1977, a report by the InterAmerican Development Bank (IDB) referred to Nicaragua's forests as 'idle resources' that could be put to productive use through conversion to agriculture or pasture [25]. Throughout Latin America, forests were the land banks for planned colonization or settlement programs that were organized as part of agrarian reform policies, and colonists were encouraged or required to clear them. Hence, until recently, deforesting the land was seen as a measure of invested labor [26] that demonstrated the 'social use of land' and was often a requirement for obtaining legal title. Underlying this process was the concept that 'work constituted a basis for ownership, rendered visible through land clearance' [27,28]. Even when titles have not been forthcoming, land markets have commonly arisen around cleared areas as buyers purchase these labor investments, known as mejoras (improvements), even if they cannot legally purchase the land itself.

The pattern of development based on natural resources reinforced, and was reinforced by, a social system that placed top priority on land ownership as a source of wealth and prestige. The colonization of forest land was tied both to the expansion of latifundia (large landed estates or ranches) into these regions and to the needs of small farmers and peasants who were pushed out of more desirable areas. Extensive ranching was a common way to claim large tracts of land, and the movement of agricultural frontiers has often involved a combination of dynamics resulting in the conversion of forest to pasture.

Though large areas of the region's forests have been home to indigenous people historically, their land claims had little effect on economic development policies due to the status and treatment of these populations. Indigenous policies after independence were initially aimed at annihilation, then forced removal to reservations, and, finally, to indigenismo, which aimed 'to transform Indians into undifferentiated citizens'; this policy was broadly adopted by 1940 and is still predominant in laws enacted as recently as the 1980s [29]. Indigenous lands and the natural resources on and under them were claimed by the state and given in concession to private companies.

The mid to late 20th century in Latin America was also marked by the prevalence of centralized states in the context of authoritarian regimes. The return to democratically elected governments paralleled the increasing recognition globally of the importance of forests and forest conservation and 
the rise of the international movement for indigenous rights. These important new dynamics converged with new ideas in development, such as Agenda 21, approved at the 1992 UN Conference on Environment and Development in Rio de Janeiro, which pushed 'sustainable development' onto the international stage.

The shift toward democratic governance in the region went hand in hand with the promotion of decentralization policies, which were aimed at increasing the role of local governments in state administration and 'bringing the state closer to the people' [30]. Conservation interests brought to international attention the importance of forests and biodiversity conservation, resulting in a series of policies aimed at creating protected areas and integrating conservation and development. Indigenous people won unprecedented recognition in international spheres and began to win important rights at home, particularly to their ancestral territories, often forests. They sometimes worked together with conservation organizations, but also found themselves in conflict with these groups over rules and restrictions on resource use.

At the same time, macroeconomic policies were changing the role of the state in Latin American development. By the mid 1980s, economic structural adjustment policies forced state downsizing and the contraction of fiscal spending. In much of the region, existing state-led agrarian reforms were replaced with market-based reforms and an emphasis on modernizing cadastres and land registries. The market, rather than the state, was to become the main driver of economic development.

This brief history provides the context for understanding the central problems in forest governance today. The institutional arrangements for state forest administrations in Latin America have often reflected the primacy of agriculture over forests and the failure to address forests as more than a source of timber and land. These agencies tend to be weak, underfunded and overly bureaucratic, regulating logging permits rather than forests. They are faced with — and sometimes part of - vested interests in forests and forest lands that are deeply rooted and sometimes highly conflictive.

\section{Forest Governance in Latin America: Risks and Opportunities for REDD+}

The next six sections address central aspects of forest governance in Latin America today and their relation to REDD+. Though the issues addressed here are highly interrelated, the first three look more through the lens of who makes decisions, while the last three focus somewhat more on how. Both aspects, of course, are relevant to what decisions are being made regarding forests. For each issue, we discuss the current situation in Latin America and both risks and opportunities for REDD+ in light of current governance dynamics.

Section 5, 6 and 7 examine scales of decision making, discussing, in turn, central government institutions, decentralization and devolution. Who makes decisions under REDD+, and the relationship among entities from central to subnational and local scales, has implications for the kinds of policies and projects that are implemented and the distribution of benefits and burdens. REDD+ ups the ante on decision making: It offers an unprecedented source of funds, either through a global REDD+ regime, multilateral or bilateral partnerships or both, to support the kinds of decisions that may not even have been considered previously, such as aligning policies that affect forests across sectors and scales.

Sections 8, 9 and 10 explore three issues affecting how decisions are made: The forest bureaucracy, corruption and illegal logging and citizen participation. Decision making in forestry should presumably 
be based on an informed understanding of the relevant natural and social problems and opportunities facing forests. Yet, as mentioned earlier, good forest management has been overshadowed historically by decisions and practices dominated by the economic and political concerns of different interest groups. If these problems are not addressed, they could undermine the potential benefits of REDD+.

\section{Central Government Institutions}

Though important new strategies have been promoted to support conservation with livelihood benefits, central government institutions involved in forests are often divided by sector or subsector and fail to integrate policies on forests. In particular, forest policies and institutions have little relation to the many other central government institutions and policies that affect forests. Overcoming this problem is one of the most important opportunities offered by REDD+.

Up until 1990, state forest administrations were normally located under the ministries of agriculture [24], but today they are more often semi-autonomous bodies responsible for the planning and supervision of forest management (usually logging) under environment ministries, which define, implement or enforce broader forest policies [24]. In the past two decades, these entities together have adopted a variety of policies, schemes and instruments to foster conservation and sustainable forest use. For example, a few countries have promoted payments for environmental services (PES) and other forest financing schemes [31] or community forestry initiatives (CFEs) [32]. Nevertheless, these have often emerged less through broad governance reforms and supportive state policies and more through specific project approaches (though Mexico is an important exception) [32]. Boscolo et al. [31] argue that to have broader appeal throughout Latin America, the 'attractiveness of the forest sector ... and its institutions' has to improve.

In particular, policies arising mainly from forest and environment agencies are largely insufficient for a more integrated approach to forests and forest management for multiple values. Such an approach is dependent not only or even primarily on decisions by forest agencies but also by agencies - usually far more powerful — with mandates on policies affecting forests. Therefore other central agencies such as Ministries of Agriculture or infrastructure, central banks or Ministries of Finance have a key role to play in ensuring an integrated approach to forests. In fact, the decisions with some of the highest impacts are often made at the presidential level.

These decisions involve investments in macroeconomic and trade policies, roads and other infrastructure, and policies regarding agriculture, land tenure and so on. For example, globalization and macroeconomic policies such as trade liberalization and structural adjustment have stimulated deforestation in lowland Bolivia, due to dramatic increases in investments in industrial production of soy, wheat and sorghum [33]. These and other macroeconomic policies adopted by LA governments opened a competition between global and domestic markets for food, fiber and biofuels and forests. In addition, biofuels targets set by the EU, United States, Brazil and others, although based on environmental concerns, may have unpredictable direct and indirect impacts on forests as they are likely to require more and more land [34], (see Box 1 and Figure 1). 
Box 1. The potential impact of biofuels expansion on forests.

The demand for biofuels highlights the complexity of the issues facing climate change mitigation efforts, whereby attempts to address fossil fuel use on the one hand (to lower $\mathrm{C}$ emissions) may promote deforestation on the other (causing higher $\mathrm{C}$ emissions and promoting the loss of other forest values). Figure 1 shows that currently land suitable for biofuel crops such as rape or oil palm or soya, is either occupied by forests (in red) or by agriculture (in yellow). Only a relatively small area of the land suitable for each respective crop in Latin America is actually available for its cultivation. The least land is available for oil palm. The implication is that an expansion of oil palm, as well as other crops to a lesser degree, will either replace forests and lead to deforestation or replace other crops on agricultural lands, or both [34]. Hence, policies in other countries and regions spur global markets, which in turn can lead to deforestation in unexpected ways.

Figure 1. Current uses of land suitable for biofuel crop expansion in South America. Source: $[34,35]$.

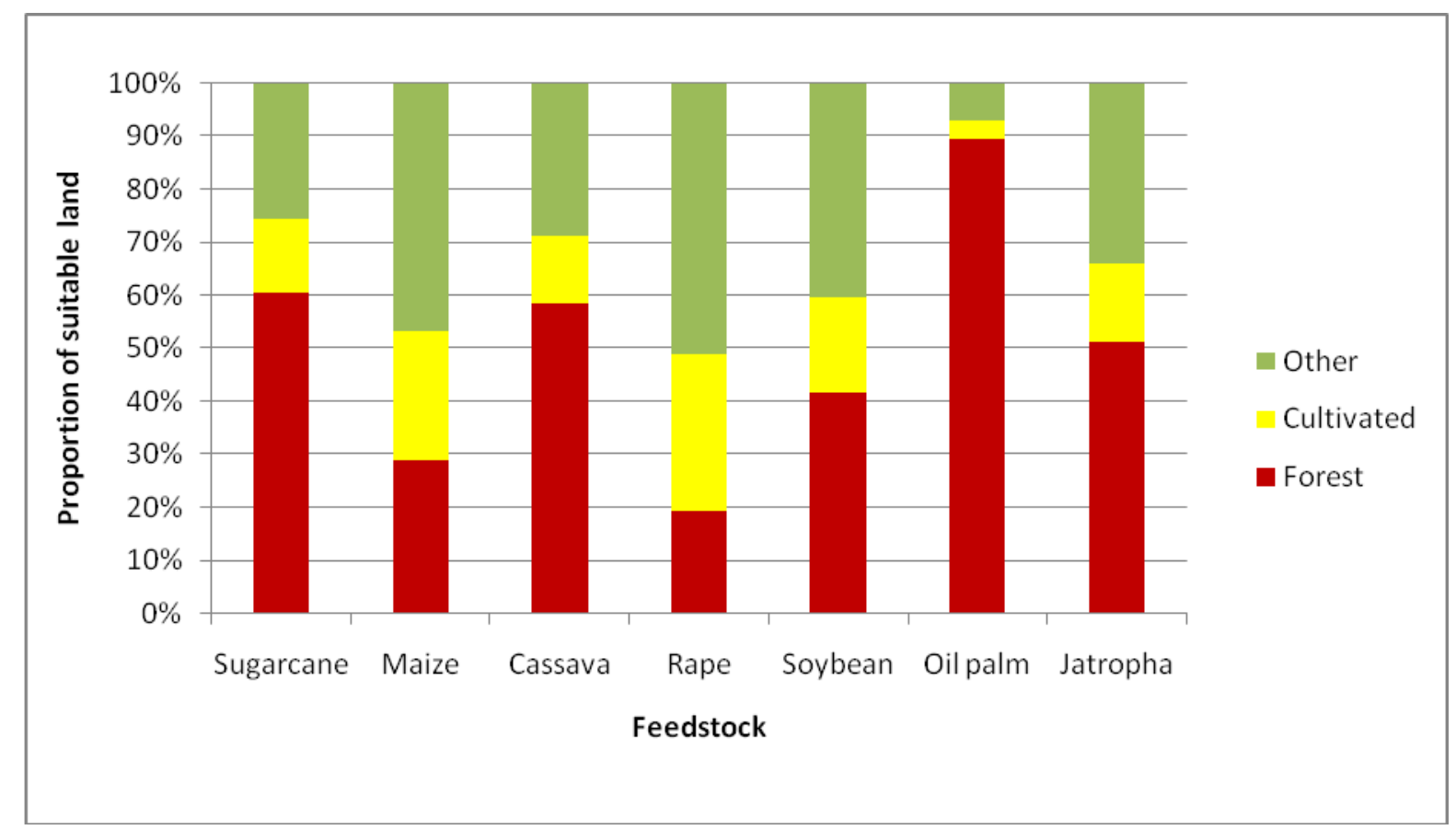

Land speculation and forest clearing for pasture have also been driven by infrastructure developments, particularly roads, combined with fiscal incentives and credit policies, promoted by central agencies other than environment ministries [36-38]. Recent reforms in Brazil demonstrate a more integrated approach that aligns lending, land use, and market policies, to address specific drivers of deforestation (see Box 2). It provides an example of an approach aiming to preserve forests but not limited to the forest sector. 
Box 2. Policies to curb deforestation in Brazil.

Brazil adopted a series of policies to address drivers of deforestation, including [39]:

- Farmers who apply for a bank loan must provide evidence that they are in compliance with a 1980 law limiting the amount of forest that can be cut on any parcel that is brought under cultivation, varying from $80 \%$ in the cerrado (savanna woodland) to $20 \%$ in Amazonia (humid tropical forest).

- An earlier provision that allowed farmers to deforest one parcel and meet the forested quota on another at a different location led to considerable abuse, so the provision has been removed.

- A two year moratorium was introduced in 2006 to stop the purchase of soya grown on land deforested after that date in the Amazon. The moratorium was extended to mid 2010 and expanded to include properties of less than 100 ha.

- Farmers face increasing pressure to register their properties, which facilitates monitoring.

Risks and opportunities for REDD+. Addressing competing economic incentives for forest clearing - whether market or policy based - is one of the most important opportunities offered by REDD+. REDD+ is fundamentally a financial mechanism that can make forest conservation and sustainable management an economically attractive alternative to forest clearing or to degradation through unsustainable use. Performance-based payments provide an important incentive to demonstrate success.

REDD+ can potentially be a framework for a broad assessment of the root causes of deforestation and forest degradation and comprehensive political and economic responses by national governments. REDD+ could strengthen and increase the capacity of forest and environment institutions and provide an opportunity and an incentive for intersectoral and multiscalar coordination and problem solving, across agriculture, infrastructure and macroeconomic policy institutions. Arrangements for the management and resolution of intersectoral conflicts, for assessment of trade-offs between development objectives or different actors' interest and for alignment of policies across sectors are needed, combined with a clear government priority to support forest sustainability.

If REDD+ policies only emerge from a forest or environment ministry without corresponding commitments from decision makers in agricultural and economic ministries, results will be partial at best. Without an integrated approach to all aspects of development and markets affecting forests, gains through reduction of carbon emissions through policies in one sector will be counterbalanced by losses through incentives for deforestation and degradation in another.

\section{Decentralization and Local Government}

The issue of who makes decisions about forests not only involves central level coordination but also decision making across scales. Decentralization policies have been promoted throughout Latin America in recent decades, as mentioned above, as an important element in the return to democratic government regimes. Policies reintroduced or established systems for the democratic election of subnational and municipal governments, promoted some autonomy at these levels and institutionalized citizen participation (discussed below). REDD+ can be designed and implemented centrally or in a 
variety of ways that take advantage of or promote decentralized entities, such as through nested approaches [40]. Irrespective of the distribution of power and responsibilities across scales, REDD+ will require that these roles be clearly defined, without competing or contradictory mandates, and that processes for resolving competing interests are in place.

Decentralized decision making has been promoted with extensive democratization discourse, yet the results in practice have been mixed. Subnational and local governments have not necessarily been effective, accountable, representative or responsive to citizens, but one important aspect of the problem is that decentralization has not often been implemented effectively. In his review of five different analyses of political decentralization in the region, Mitchell [41] reaches the pessimistic conclusion that 'national parties and political bureaucracies may try strenuously to maintain centralized control'.

Decentralization in the forestry and environment sectors specifically has been even more recent and tentative; it has suffered from similar problems of ongoing centralized and somewhat opaque control of decision making. In fact, it has both advanced and receded, depending on the specific negotiation at hand, often in the same country at the same time [42]. A study of forestry decentralization experiences in Bolivia, Brazil, Guatemala, Honduras and Nicaragua found that where powers were being decentralized at all, this was being conducted on a case-by-case basis by contract — a strategy that runs the risk of maintaining decisions at the central level in practice $[42,43]$.

Decentralized approaches, however, are important for understanding forest dynamics at local and regional scales and identifying effective solutions. For example, Pacheco et al. [16] develop a typology of five economic actors that each shape Latin America's forest landscapes differently and respond in distinct ways to market dynamics and public policies. They argue that a single policy approach-to making sustainable forest management or conservation a more attractive economic alternative-will not work for all. Adaptive approaches that take into account local realities and dynamics can be best designed and implemented at subnational level, suggesting the importance of some degree of decentralization for REDD+.

Risks and opportunities for REDD+. Some people have suggested that the way in which REDD+ is developing - with demonstration activities already underway while the global framework and national policies are still under negotiation — presents an important opportunity for 'bottom-up' design; these diverse models of 'learning by doing' could significantly shape the global agenda [44]. A recent study found that 31 of 100 identified demonstration projects were located in the Amazon, and 12 in Central America and the Caribbean [45], suggesting that the LAC region will have important experience to contribute.

The decentralized implementation of at least some REDD+ policies and projects provides the opportunity for local input into design and better targeted solutions. REDD+ readiness should be judged by whether several conditions regarding subnational governments are met:

- Clear mandates of national and subnational governments in regard to REDD+. The most important role of subnational governments could be to ensure that REDD+ policies and projects reflect and are adapted to local realities and needs.

- Clear and adequate distribution of REDD+ funds, according to mandates. 
A significant investment will be needed to build subnational government capacity so that they can adequately adapt REDD+ design to local realities and to ensure these governments' downward accountability for the use of the REDD+ resources allocated to them.

At the same time, central organization and oversight would permit greater attention to the national policy environment and some of the most important indirect or larger-scale drivers of deforestation and degradation. It would also permit greater attention to the control of leakage. Various researchers agree that neither fully centralized nor fully decentralized options are ideal [46,47], but given the resistance of central entities to decentralizing decision-making powers, effective decentralization in general may depend on the capacity of local governments to fight for and take advantage of decentralized spaces — or 'demand from below' $[48,49]$.

\section{Devolution and Local Forest Rights}

The rules, regulations and processes defining forest governance are intimately related to forest tenure, or property rights, as these rights define who has what use and decision-making rights over forests and forest resources [50]. REDD+ success requires clear forest tenure rights and depends on obtaining the support of people living in forests to reduce carbon emissions.

At least until recently, the state has usually maintained the ownership of forests and forest resources and the right to grant concessions with or without the consent of people living in or near those forests. This is still true in some countries, under at least some tenure regimes, and it is almost universally true for subsoil resources such as minerals and petroleum. It is also true for conservation. A study of 88 Global Environment Facility (GEF) biodiversity projects in Latin America found that 81 projects supported state protected areas 'that imposed restrictions on access and use by indigenous and local peoples' [51].

Yet, the situation is changing. Land tenure policies granting new rights to forest-based communities, the creation of forest user groups and various types of co-management arrangements, as well as the promotion of community forestry [32], have recognized the role of local people and communities in forest management. Most importantly, many people living in Latin America's forests-particularly indigenous peoples and traditional communities - have sought the formal recognition of their rights based on ancestral or other land claims [52]. Today, a quarter of LAC forests is owned by these communities and another $8 \%$ is designated for their use [53]. In particular, indigenous peoples in several countries have obtained titles to large forested territories. This represents an important shift in decision-making rights about forests, from the state to communities or local people, at least in theory.

This policy shift, however, is incomplete. A study of tenure reforms aimed at strengthening community rights in seven subnational regions in Bolivia, Brazil, Guatemala and Nicaragua found that rights granted on paper were often weakened by the loss of rights to competing actors during demarcation and other implementation processes [54,55]. Almost all reforms have faced resistance, ranging from foot dragging and backtracking by some state entities charged with implementation to competition for land and resources with the state, colonists and a variety of other actors [56-59]. Though international agreements such as the United Nations Declaration on the Rights of Indigenous Peoples, and sometimes national legislation, protect the right to free prior and informed consent (FPIC), traditional knowledge and equity of benefits, these provisions are not always applied in practice. The 
result is a lack of clarity regarding forest rights, or conflict in practice even if rights appear clear on paper.

Risks and opportunities for REDD+. Grassroots and indigenous organizations have raised concerns or even directly opposed REDD+ as they fear that their rights will be undermined by more powerful actors, as has happened in other cases [60]. Even if land and forest tenure rights are secure, carbon rights have still not been clarified and may be obtained by outsiders or usurped by political leaders.

REDD+ requires clear and secure rights and exclusion of those who cause deforestation and degradation. This is an opportunity to clarify and secure rights (and associated benefits and responsibilities related to $\mathrm{C}$ emissions reductions) of people living in forests and thus engage them in REDD+ for both their benefit and the benefit of the forests. By doing so, REDD+ will gain their support - and therefore its legitimacy. It could consolidate new large indigenous territories [52], avoid conflict and operate in a stable and supportive environment. The reverse-failure to protect the rights of forest-based peoples - is likely to lead to increased conflict, opposition and even the sabotaging of carbon reduction efforts.

\section{State Forestry Bureaucracy}

Forest and environment agencies are likely to lead the implementation of national REDD+ initiatives and be responsible for operating various implementation systems, such as approving and overseeing projects, establishing reference levels and rules for compliance, designing and overseeing monitoring and reporting systems, and others. The relocating of forest administrations in a number of countries to environment ministries has often been accompanied by broader reforms. Some countries completely restructured their forestry services in the 1990s (e.g., Bolivia, Guatemala, Mexico, Peru). Others have done so more recently (e.g., Honduras).

One area of state forest administration that has improved significantly is forest statistics and information. New forest inventories have been completed in four Central American countries (Costa Rica, Guatemala, Honduras, Nicaragua) and are underway in four South American countries (Brazil, Ecuador, Peru, Uruguay) [61]. Online information systems have been created in numerous countries, including Mexico, Nicaragua, El Salvador, Colombia, Peru, Bolivia and Panama. An evaluation of the results in the last four countries found them to have 'significantly contributed to increasing country capacity to collect and analyze trustworthy forestry information' [62]. Nevertheless, questions have been raised about the accuracy of forest inventories, but perhaps even more important, ITTO [24] reports that the 'findings have rarely been used, either by forest operators for the detailed planning of their logging or by the forestry services for issuing logging licenses.'

The move of forest agencies to environment ministries places a stronger emphasis on conservation, but the shift is insufficient, and little has changed in the overall emphasis on timber, excessive bureaucracy regarding logging and the tendency for both environment and forestry agencies to impose unnecessary and sometimes unrealistic rules and regulations on forest-based populations. Rather than manage forests, forest bureaucracies tend to manage permits. Today, logging in the vast majority of natural forests in Latin America requires management plans [24], which were created to avoid unsustainable practices based on scientific principles. Nevertheless, they have often become simple 
bureaucratic prerequisites. In fact, they may represent the epitome of an over-burdening bureaucracy. Before the new Forestry Law was passed in Honduras in 2007 (Forestry, Protected Areas and Wildlife Law, Decree 98-2007), for example, obtaining a logging permit involved 20 actors, 53 procedures and 71 different steps, and took an average of three to four months; in Costa Rica, the process required 11 actors, 31 procedures and 34 steps and could take up to 1.5 years [63]. Procedures that are difficult, time consuming and costly for private companies often present insurmountable barriers for communities and smallholders. In Bolivia, approval has been known to take over two years for a community management plan [58]. In Brazil, attempts to simplify regulations have also been fraught with bureaucracy for smallholders and communities [64].

In addition, laws and regulations tend to be inadequate, contradictory and leave substantial maneuvering room. They may exist only on paper-either because they are not enforced or are not enforceable. Though it is broadly recognized that some kind of regulation is needed to guarantee the future of the world's forests, it is apparent that many regulations serve less noble purposes, including maintaining government jobs and authority and favoring elite actors [65,66], or rent-seeking and corruption [67]. Excessive bureaucracy also makes non-forest activities more attractive and provides incentives for forest conversion or to avoidance of the law [68].

With regard to communities living in forests, both forestry and conservation agencies may impose rules and regulations without having a clear understanding of existing or customary practices related to forests. In Guatemala, conservation-inspired restrictions, such as those placed on sheep farming, firewood use and the use of pinabete (Abies guatemalensis Rehder), a highland pine species popular for Christmas trees, appear to affect the poorest families most, forcing them to bear the costs of protection without offering any alternatives or compensation in return $[69,70]$. In Nicaragua the sudden imposition of a logging moratorium led to losses of over $\$ 28,000$ for the most prominent community forestry organization in the country [56].

Risks and opportunities for REDD+. REDD+ requires substantial, accurate information, including comparable uniform standards, in order to monitor carbon stocks and compliance with agreements. Forest agencies will have to improve by necessity their capacity to generate data and information to demonstrate performance under a REDD+ regime. However, there is an opportunity to combine expert data with participatory monitoring and to produce information that can be also used in decision-making and by constituencies other than the government. REDD+ funding can - and inevitably will - strengthen forest agencies' focus on forest conservation and shift away from their current emphasis on timber extraction. REDD+ could provide an opportunity to overhaul policies, laws and regulations associated with forests. The design of this legal framework will require new capacities and innovation. In this sense, it can re-invent forest agencies and transform them into true guardians of the forests and their multiple values.

Yet there are also risks. The emphasis on carbon emissions under REDD+ could also lead to bureaucratic management that parallels that of logging permits rather than promoting the multiple values of forests. Complex and time-consuming regulations mean transaction costs for REDD+ are likely to be high and it may not be competitive with other forest uses. And complex rules may remain on paper and have no relation to what is happening on the ground. Narrow, top-down decisions to try to bring about the changes in behavior required for carbon emissions reductions may fail to take into account local variation and to distribute burdens and costs equitably. Traditional, long-standing links to 
logging concessionaries as well as an institutional culture focused on extraction may create conflicts, tensions and resistance inside agencies, which will be detrimental to REDD+ in several ways. First, officials may resist and undermine innovative policies, rules and activities in support of REDD+. Second, some timber concessionaries may use their connections in the forest agencies to gain advantage from REDD+ at the expense of others. And finally, resistance and opposition inside the agencies may make them ineffective and unable to deliver on commitments.

\section{Corruption and Illegal Logging}

Good forest governance means that laws and rules are enforced equitably. Corruption and illegal logging, and particularly the vested interests behind them, foster bad governance and obstruct efforts to promote sustainable forest practices. They pose both direct and indirect risks for REDD+ by facilitating degradation and creating opportunities for elite capture or diversion of REDD+ funds.

According to the World Bank, the annual cost of illegal logging globally was over US\$10 billion in 2006, and annual losses in government revenues totaled about US\$ 5 billion. The 'failure of forest governance — characterized by illegal logging, associated illegal trade, and corruption — undermines... attempt[s] to achieve sustainable economic growth, social balance and environmental protection'; illegal logging depends on corruption, hence linking law enforcement capacity and expertise in the forest sector with efforts to fight corruption and money laundering generally can reduce forest crime [71].

Corruption also ensures elite capture, which occurs through both legal and illegal forest activities. Thus it places a heavy burden on the poor who pay the most for it, both in terms of absolute numbers and as a share of their income. Better rule of law is associated with increased income [72,73], hence illegal logging and corruption are obstacles to improved income for local people and poverty alleviation. Time series data, from 1996 to 2008, for the World Bank's Control of Corruption indicators found that the ten Latin America countries studied (Brazil, Bolivia, Chile, Colombia, Costa Rica, Ecuador, El Salvador, Mexico, Peru, Venezuela) exhibited widely varying ability to control corruption, and relatively stable levels of corruption over the 12-year period [74]. This means that, in general, countries have not significantly improved control of corruption for more than a decade.

With regard to the control of forest crime specifically, a review of the systems verifying timber legality in Costa Rica, Honduras, Nicaragua and Brazil shows that the institutions charged with overseeing forest crimes generally have limited capacity and funding (see Table 1), frequently depend on timber interests or even income from logging, and their ability to perform is obstructed by a confusing regulatory framework, as mentioned above. Nevertheless, Brazil has invested in a timber legality verification system that is strong and independent, both in its legal framework and organizational design and capacity. This system is also designed to be transparent, multiscale and nationwide. Monitoring compliance has been greatly facilitated by the availability of affordable, up-to-date satellite images. This, along with the adoption of some supporting extrasectoral policies (Box 2), may have contributed to the reduction in deforestation in Brazil, from 2.7 million ha per year in 2003-2004 to 1.15 million ha per year in 2006-2007 [39]. 
Table 1. Capacity, independence and legal certainty for institutions charged with logging oversight in selected countries in Latin America (Adapted from [75]).

\begin{tabular}{|c|c|c|c|c|}
\hline Capacity/Country & Costa Rica & Honduras & Nicaragua & Brazil \\
\hline $\begin{array}{l}\text { Level of government } \\
\text { funding for agencies } \\
\text { verifying legality of } \\
\text { timber }\end{array}$ & Insufficient & Insufficient & Extremely low & Mostly sufficient \\
\hline $\begin{array}{c}\text { Financial independence } \\
\text { and political support to } \\
\text { agencies verifying } \\
\text { legality of timber }\end{array}$ & $\begin{array}{l}\text { Centrally funded but } \\
\text { field operations depend } \\
\text { on logging companies }\end{array}$ & $\begin{array}{l}\text { New agency } \\
\text { under the } \\
\text { Presidency has } \\
\text { financial } \\
\text { autonomy }\end{array}$ & $\begin{array}{c}\text { Information not } \\
\text { available }\end{array}$ & $\begin{array}{l}\text { Strong political mandate, } \\
\text { inter-institutional } \\
\text { coordination, two } \\
\text { independent levels (federal } \\
\text { and state); but field } \\
\text { oversight and enforcement } \\
\text { paid by industry thus } \\
\text { leading to some dependence } \\
\text { on logging companies }\end{array}$ \\
\hline $\begin{array}{l}\text { Legal and regulatory } \\
\text { certainty and } \\
\text { comprehensiveness }\end{array}$ & $\begin{array}{l}\text { Relatively stable legal } \\
\text { framework, but too } \\
\text { complex and difficult to } \\
\text { comply with. No clearly } \\
\text { defined sanctions for } \\
\text { non-compliance. } \\
\text { Regulatory and } \\
\text { management functions } \\
\text { not clearly defined. }\end{array}$ & $\begin{array}{c}\text { Regulatory and } \\
\text { methodological } \\
\text { gaps }\end{array}$ & $\begin{array}{c}\text { Confusing and } \\
\text { overlapping } \\
\text { laws, legislative } \\
\text { uncertainty and } \\
\text { gaps, missing } \\
\text { mandates. }\end{array}$ & $\begin{array}{l}\text { Coherent framework, } \\
\text { responsibilities of forest } \\
\text { professionals monitoring } \\
\text { management plans not } \\
\text { clearly defined. High levels } \\
\text { of transparency of forest } \\
\text { licensing information } \\
\text { support enforcement. }\end{array}$ \\
\hline
\end{tabular}

The independence and transparency of a system and its component parts - both the agencies involved in timber legality verification and other arms of the executive, judicial or legislative branches - are widely accepted as key factors for reducing forest crime, including corruption and illegal logging and trade. The vested interests behind these are the main obstacles to reform. Civil society and external actors, including donors, can be important drivers of good governance [76]. Civil society organizations can act as watchdogs (e.g., the Forest Integrity Network, Global Watch, Amazon Watch, Bank Track); strengthen legality and sustainable management (e.g., the Forest Legality Alliance, the Forest Trust); promote transparency and participation in forest-related decisions (the Global Forest Initiative, the Forest People's Programme) and so on.

Risks and opportunities for REDD+. Corruption and illegal logging can indirectly weaken REDD+ by undermining reform efforts designed to support its objectives and increasing the risks associated with REDD+ investment. Illegal logging and corruption also pose direct risks for REDD+, as REDD+ is associated with potentially large sums of money. Corrupt practices, such as the diversion of funds in the transfer and payment of REDD+ compensation, will undermine the ability of governments to effectively curb deforestation and forest degradation. Elite capture will undercut the legitimacy of and support for REDD+. Further, reductions in carbon emissions through REDD+ initiatives could be offset by increases caused by illegal activities. 
REDD+ can improve governance and reduce direct or indirect risks for its success, if national REDD+ strategies, programs or reforms, and the donors supporting them, integrate efforts to build government capacity to enforce the law, reduce illegal logging and curb corruption, and engage and strengthen the role of civil society to promote good governance and to contribute to REDD+ implementation in various roles and at various scales.

Further, funding for REDD+ brings the opportunity for structural change. If it makes sustainable forest management and forest conservation economically viable, it will be able to re-direct investment from forest-destructive activities, reduce the risks for corrupt practices and make illegal logging less attractive.

\section{Citizen Participation}

Citizen participation and involvement in decision-making is considered to be an important aspect of good governance in general, even though concerns have been expressed that it may be a new form of tyranny - creating opportunities for manipulation and facilitating unjust use of power [77]. In Latin America, however, grassroots participation has been promoted by a wide range of social movements and a strong and vibrant environmental justice movement. Substantive grassroots participation in REDD+ negotiations and strategies is seen as fundamental to equity and legitimacy, but REDD+ has provoked some important organized objections, in part based on environmental justice principles [78].

Environmental justice is deeply rooted in the region, from local to transnational scales. The movement's pillars are distributional inequity and procedural inequity, promoting the search for 'greater political participation and more authentic citizenship' [79]. Urban, women's, labor, religious and other organizations and movements have been 'remapping social relations' throughout the region. Intellectuals have supported a multitude of non-governmental organizations (NGOs) based on a 'strong tradition of academic activism'. Indigenous movements have been central actors in mobilizing for rights over ancestral lands, frequently in forests, and a place at the negotiating table on policies affecting their rights or livelihoods [79]. Latin American governments have responded by putting in place legislation and mechanisms to streamline and institutionalize participation. Today, many LAC countries have Constitutional provisions and laws to promote justice, participation [80] and access to information [81] (see Figure 2). These legal frameworks change the relationship between the public and its social organizations and the government $[82,83]$.

Despite these laws, however, the relationship between the public and the decision-makers remains complex. Marginalized, isolated groups have little access to information. Participation is limited to public consultation and rarely includes dialogue on policies; consultation occurs once implementation has already started, when it is too late to incorporate public input. Marginalized groups such as indigenous peoples are frequently excluded. Weak accountability is a barrier to public involvement in decisions as well. Limitations on who can seek judicial and administrative action; on what issues such action is possible; complex, expensive and time-consuming procedures - all of these are barriers to public involvement in strengthening accountability. With regard to natural resources, inadequate courts or mechanisms and judges with little or no understanding of environmental or related social issues have failed to resolve conflicts over external intervention, economic development and exploitation of forests, fields, fishing places and water resources [82]. 
Figure 2. Presence and quality of legal frameworks for participation and access to information in Chile, Colombia, Dominican Republic, Ecuador, Guatemala, Honduras, Mexico, Nicaragua, Panama, Peru and Uruguay (Data from [82]).

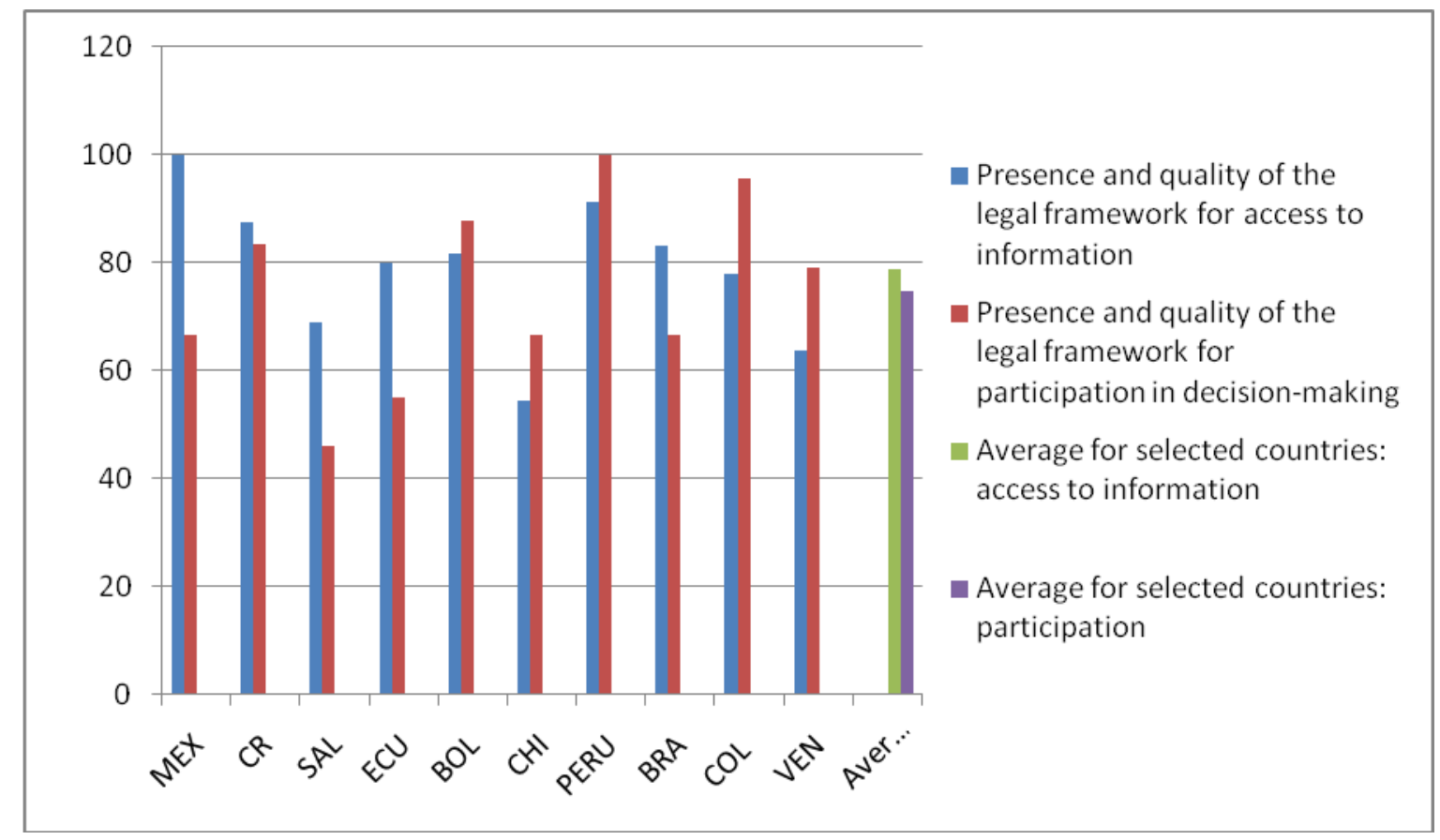

Risks and opportunities for REDD+. The failure of many governments to involve grassroots organizations and interested groups in national strategy design so far [84] presents risks for REDD+. Social organizations, NGOs and indigenous groups from Latin America have a strong stake-and increasingly, defined positions - regarding REDD+ design, who should be involved and how benefits should be distributed. Exclusion of these groups from policy dialogues and projects leads to resistance and conflict and the undermining of legitimacy for REDD+, jeopardizing chances for success. Given past experience, the level of funding and technical requirements associated with REDD+ may reinforce bureaucratic tendencies to centralize decisions of all kinds and promote closed-door decision making, which allows undue influence by vested interests.

In contrast, transparency and participation help avoid conflict and resistance. Citizen participation is relevant to REDD+ for at least two main reasons. First, citizens can provide valuable input to REDD+ policies and strategies. Second, citizens - particularly those living in or near forests-are important stakeholders in the design of both national REDD+ policies and projects on the ground and should be fully informed of their implications. An early and substantive dialogue and an effort to reach mutually beneficial agreement on how REDD+ should work at all scales will gain support, engage the interest of affected and knowledgeable groups and is more likely to result in mutually acceptable, and better, policies and projects and better implementation by a broad constituency.

\section{Forest Governance and REDD+: The Need for Effectiveness and Legitimacy}

This review of challenges in forest governance in Latin America suggests that the conditions for good forest governance discussed in the introduction have not been met, though there has been important progress in some arenas. On the one hand, REDD+ has the potential to influence forest 
governance positively and promote and strengthen positive trends. In fact, its success depends on it. On the other hand, however, it may end up being shaped by inherited problems and current deficiencies in forest governance.

The challenges are numerous:

- lack of integrated approaches to forests and, hence, contradictory policies leading to incentives for deforestation

- overly centralized decision making

- bureaucratic, narrowly focused and top-down approaches

- weak capacity among forest and environment institutes and local governments

- scientific information not used for decision making

- corruption and elite capture of benefits

- confusing and complex legal framework and inadequate application of the law

- competition and lack of clarity regarding forest tenure and carbon rights

- weak implementation of participation mechanisms

How are all of these relevant to REDD+? As stated earlier, REDD+ is primarily a financial, not a governance, mechanism. It will be affected by governance and it can also affect governance, though REDD+ certainly cannot solve all the problems of forest governance in Latin America. The fundamental benefit of REDD+ is that it is offering funding on a scale never before seen, to permit standing forests to compete with incentives and markets that would otherwise promote forest clearance or degradation. At its best, it would shift development priorities and promote a new, sustainable development model. At a minimum, it should offer alternative livelihood options to local forest peoples and alternative income sources for other actors pursing economic interests that compete with forest conservation. Because payments are contingent on performance, better laws and rules might emerge. Transparent accounting systems could help curb corruption. It might alter the incentive structure such that illegal logging is no longer attractive.

At the same time, however, granting substantial amounts of new funding for forests under existing problematic governance conditions can just as easily fuel corruption and elite capture, increase the stakes for vested interests, promote centralized decision making and control and provide incentives for land grabbing. Attempts at reform in the past demonstrate resistance to change, such as to a more integrated approach to forests, and particularly to changes in the structure of decision making, the status quo of the state bureaucracy and forest property rights.

Governance deficiencies present threats to REDD+ in two main ways. Some will have a negative impact on its effectiveness; others are likely to undermine its legitimacy.

Effectiveness refers to the ability to decrease carbon emissions. Most critical for REDD+, is the accurate assessment of the drivers of deforestation and degradation, at appropriate scales, and the design of specific policies, strategies and institutional mechanisms to address them. The key in the alignment of macroeconomic, lending, sectoral and other policies will be to make REDD+ economically viable so that illegal logging and forest land conversion to other uses is no longer an economically attractive alternative to forest conservation. Only then will gains through REDD+ not be offset by increased emissions in forests caused by development in other sectors. Designing such 
policies would include building institutions for the assessment of trade-offs between different development objectives and for the management and resolution of intersectoral conflicts.

Subnational and local governments are important players who can contribute to a REDD+ design that reflects and is adapted to local realities and needs. REDD+ effectiveness will also be influenced by whether the mandates of national, subnational and local governments with regard to REDD+ are clear and consistently implemented.

REDD+ will require clear and coherent legal framework in the forest sector itself. While current forest policies are often contradictory and confusing, resulting in poor enforcement and corruption, REDD+ could provide an opportunity to overhaul them. The design of this legal framework will require new capacities and innovation. REDD+ provides an opportunity to re-think the existing institutional framework, renovate entrenched bureaucracies, and experiment with alternatives.

REDD+ success also depends on its legitimacy, which will, in turn, depend on its ability to gain broad support and engagement from indigenous groups, civil society, local governments and other stakeholders. For many of these groups, REDD+ raises concerns regarding global environmental justice, associated with the failure of nations causing global climate change to reach a binding agreement to limit their own carbon emissions. It is important to note that this issue interferes with the ability of REDD+ to obtain broad-based legitimacy in the political culture of Latin America.

At the national and subnational scales, other factors play a central role in legitimacy. Among these, tenure rights and the distribution of benefits and burdens are of paramount importance, as these will directly affect millions of people whose livelihoods depend on forests. Their acceptance — or rejection of, resistance or opposition to REDD+— will either ensure its legitimacy or lead to conflict and undermine it. Social safeguards should ensure the protection of local tenure rights and the effective use of mechanisms such as Free Prior and Informed Consent.

REDD+ legitimacy also depends on broad inclusion in decision making. To increase local legitimacy, rather than declaring blanket regulatory reforms or blueprints for projects, REDD+ could be designed to promote participatory and locally appropriate decision making regarding rules and solutions to deforestation and degradation, such as through adaptive management models [85] and participatory monitoring. This would also improve effectiveness.

Inclusion is also needed at broader scales, in the design, implementation and monitoring of national REDD+ strategies. Civil society engagement as watchdogs can promote the transparency of REDD+ decisions, performance information and payments and help prevent REDD+ associated corruption and elite capture.

Addressing issues of rights, inclusion and transparency will gain legitimacy for REDD+ by making it more equitable and fair. Legitimacy ultimately contributes to effectiveness, because it encourages voluntary compliance with provisions to reduce carbon emissions. Lack of legitimacy, on the other hand, is likely to lead to opposition and conflict, increasing transaction costs or sending REDD+ funders elsewhere. Striking a balance between local legitimacy and carbon emissions reductions may prove difficult and complex and will undoubtedly involve trade-offs. For example, in the short run carbon emissions reductions may be higher if this is the top priority - but this may mean rewarding companies and other actors responsible for high rates of deforestation, human rights violations or other 'bad' track records. In the long run, however, conflict and opposition will inevitably increase costs. 
Hence the importance of deliberative forms of participation from early on in the process. In other words, without both effectiveness and legitimacy, REDD+ is likely to have limited success.

\section{Conclusions: An Agenda for REDD+}

What are the priorities for REDD+ funds and policies that would minimize the risks of bad governance and/or overcome resistance to reform? First, it is important that forestry and environment administrations have the capacity to:

- Engage in a broad policy reform with other agencies

- Overhaul forestry policy and regulations and enforce them effectively

- Use scientific information for policy decisions

- Introduce and manage systems for transparency and citizen participation

- Be independent of industry

Some of this capacity, such as enforcement, independence of industry and introduction of systems for transparency and inclusion, are linked to funding levels and institutional arrangements regarding subordination and reporting. Other capacities, such as to engage in policy dialogue with other agencies, reform forest policies with broad citizen participation, and ensure transparency of decisions and information, require new skills, attitudes and behavior.

Second, the alignment of policies across sectors cannot be achieved by forest agencies alone. If REDD+ is to be successful in supporting the alignment of policies across state entities, it will require the development of coordination and conflict negotiation mechanisms under top-level political leadership.

Third, past attempts at reform have met resistance, such as to a more integral view of forests and particularly to changes in the structure of decision making, the status quo of the state bureaucracy, and forest property rights. Civil society organizations, NGOs and particularly forest-based peoples are as important as external agreements and safeguards for obtaining the political will needed for reform at national government level, hence governments and donors involved in REDD+ should invest in transparency mechanisms, citizen participation and strengthening the ability of citizens organizations to contribute to policy reform and REDD+ design.

Fourth, particularly where civil society organizations are weak, safeguards and independent monitoring should be a priority, in order to protect the rights and livelihoods of people living in forests.

Finally, REDD+ is an opportunity to support and promote existing positive trends for reform already present in Latin America, as well as the reformers behind them. Such reforms are likely to require significant investment by both national governments and the international community now, while countries are still preparing for REDD+. An investment today is likely to determine whether REDD+ will be efficient, effective and equitable in the long run, or whether it will be accommodated in a business-as-usual governance and development model.

\section{Acknowledgments}

The authors would like to thank Pablo Pacheco and four anonymous reviewers for very useful comments on an earlier version of this article. 


\section{References and Notes}

1. Court, J.; Hyden, G.; Mease, K. Governance Performance: The Aggregate Picture; World Governance Survey Discussion Paper 3; United Nations University: Tokyo, Japan, 2002; Available online: www.odi.org.uk/resources/download/3132.pdf (accessed on 9 August 2010).

2. ECOSOC (UN Economic and Social Council). Definition of basic concepts and terminologies in governance and public administration. Note by the Secretariat, Committee of Experts on Public Administration, 5th Session, New York, NY, USA, 27-31 March 2006, E/C.16/2006/4; United Nations: New York, NY, USA, 2006.

3. Sustaining Forests: A World Bank Strategy; The World Bank: Washington, DC, USA, 2002; Available online: http://siteresources.worldbank.org/EXTABOUTUS/Resources/ gss-biodiversityreading3-forest-strategy-booklet.pdf (accessed on 28 July 2010).

4. A Decade of Measuring the Quality of Governance: Governance Matters 2006; World Bank: Washington, DC, USA, 2006; Available online: http://siteresources.worldbank.org/PSGLP/ Resources/ADecadeofmeasuringthequalityofgovernance.pdf (accessed on 9 August 2010).

5. Bell, S. Economic Governance and Institutional Dynamics; Oxford University Press: Melbourne, Australia, 2002.

6. Cotula, L.; Mayers, M. Tenure in REDD: Start-Point or Afterthought? International Institute for Environment and Development: London, UK, 2009.

7. Huitema, D.; Mostert, E.; Egas, W.; Moellenkamp, S.; Pahl-Wostl, C.; Yalcin, R. Adaptive water governance: Assessing the institutional prescriptions of adaptive (co-)management from a governance perspective and defining a research agenda. Ecol. Soc. 2009, 14, 26; Available online: http://www.ecologyandsociety.org/vol14/iss1/art26/ (accessed on 29 November 2010).

8. Oyono, P.R.; Ribot, J.C.; Larson; A.M. Green and Black Gold in Rural Cameroon: Natural Resources for Local Governance, Justice and Sustainability; Working Paper \#22; World Resources Institute: Washington, DC, USA, 2006.

9. Sandbrook, C.; Nelson, F.; Adams, W.A.; Agrawal, A. Carbon, forests and the REDD paradox. Oryx 2010, 44, 330-334.

10. Saunders, J; Reeve, R. Monitoring Governance for Implementation of REDD+. Background paper one for Monitoring Governance Safeguards in REDD+ Expert workshop, London, UK, 24-25 May 2010; Chatham House: London, UK, 2010.

11. Tacconi, L. Decentralization, forest and livelihoods: Theory and narrative. Glob. Environ. Change 2007, 12, 338-348.

12. Global Forest Resources Assessment 2005; FAO: Rome, Italy, 2006.

13. Magrin, G.; Gay García, C.; Cruz Choque, D.; Giménez, J.C.; Moreno, A.R.; Nagy, G.J.; Nobre, C.; Villamizar, A. Climate change 2007: Impacts, adaptation and vulnerability. In Contribution of Working Group II to the Fourth Assessment Report of the Intergovernmental Panel on Climate Change; Parry, M.L., Canziani, O.F., Palutikof, J.P., van der Linden, P.J., Hanson, C.E., Eds.; Cambridge University Press: Cambridge, UK, 2007; pp. 581-615; Available online: http://www.ipcc.ch/publications_and_data/ar4/wg2/en/ch13s13-3-2.html (accessed on 30 April 2010).

14. State of Forestry in the Latin American and Caribbean Region; FAO: Rome, Italy, 2004. 
15. CEPAL; FAO; IICA. The Outlook for Agriculture and Rural Development in the Americas: A Perspective on Latin America and the Caribbean; IICA: San Jose, Costa Rica, 2009.

16. Pacheco, P.; Aguilar-Støen, M.; Borner, J.; Etter, A.; Putzel, L.; Vera Diaz, M.D.C. Landscape transformation in tropical Latin America: Assessing trends and policy implications towards REDD+. Forests 2011, 2, 1-29.

17. Quijandría, B.; Monares, A.; Ugarte, R. Assessment of Rural Poverty: Latin America and the Caribbean; IFAD: Santiago de Chile, Chile, 2001.

18. Sunderlin, W.D.; Angelsen, A.; Belcher, B.; Burgers, P.; Nasi, R.; Santoso, L.; Wunder, S. Livelihoods, forests, and conservation in developing countries: An overview. World Dev. 2005, 33, 1383-1402.

19. Ayres, E. Mapping the nature of diversity: A landmark project reveals a remarkable correspondence between indigenous land use and the survival of natural areas. World Watch 2003, March-April; Available online: http://www.nativelands.org/PUBLICATIONS/Pub/ MappingDIVERSITY.pdf (accessed on 4 January 2011).

20. Red Amazónica de Información Socioambiental Georeferenciada (RAISG); Available online: http://raisg.socioambiental.org/node/106 (accessed on 10 July 2010).

21. Hall, G.; Patrinos, H.A. Indigenous Peoples, Poverty and Human Development in Latin America: 1994-2004; World Bank: Washington, DC, USA, 2004.

22. FAOSTAT. 2010; Available online: http://faostat.fao.org (accessed on 4 January 2011).

23. Lopez-Feldman, A.; Mora, J.; Taylor, J.E. Does natural resource extraction mitigate poverty and inequality? Evidence from rural Mexico and a Lacandona rainforest community. Department of Agricultural and Resource Economics, UCDARE Working Papers; University of California: Davis, CA, USA, 2006.

24. International Tropical Timber Organization (ITTO). Status of Tropical Forest Management 2005; ITTO Technical Series no. 24; ITTO: Yokohama, Japan, 2006.

25. Inter-American Development Bank (IDB). El subsector pecuario en Centroamerica, Division de Estudios Generales, Departamento de Desarrollo Económico y Social; IDB: Managua, Nicaragua, 1977.

26. Clay, J.W. Indigenous People and Tropical Forests: Models of Land Use And Management from Latin America; Report 27; Cultural Survival: Cambridge, MA, USA, 1988.

27. Barry, D.; Larson, A.M.; Colfer, C.J.P. Forest tenure reform: An orphan with only uncles. In Forests for People: Community Rights and Forest Tenure Reform; Larson, A.M., Barry, D., Dahal G.R., Colfer, C.J.P., Eds.; Earthscan: London, UK, 2010; pp. 19-42.

28. Ankersen, T.; Ruppert, T. Tierra y libertad, the social function doctrine and land reform in Latin America. Tulane Environ. Law J. 2006, 19, 69-120.

29. van Cott, D.L. The Friendly Liquidation of the Past: The Politics of Diversity in Latin America; University of Pittsburgh Press: Pittsburgh, PA, USA, 2000.

30. World Bank. World Development Report; Oxford University Press: New York, NY, USA, 1997.

31. Boscolo, M.; van Dijk, K.; Savenije, H. Financing sustainable small-scale forestry: Issues and lessons from national forest financing strategies. Forests 2010, 1, 230-249. 
32. Cronkleton, P.; Bray, D.; Medina, G. Community forest management and REDD development: Lessons from Mexico, Bolivia and Brazil. Presented at the Oaxaca Workshop on Forest Governance, Decentralization and REDD+ in Latin America and the Caribbean, A Country-Led Initiative in Support to UNFF by the Governments of Mexico and Switzerland, Oaxaca, 31 August-3 September 2010.

33. Hecht, S. Soybeans, development and conservation on the Amazon frontier. Dev. Change 2005, $36,375-404$.

34. Schoneveld, G. Potential Land Use Competition from First-Generation Biofuel Expansion in Developing Countries (Occasional Paper); CIFOR: Bogor, Indonesia, 2011.

35. Fischer, G.; Hizsnyik, E.; Prieler, S.; Shah, M.; van Velthuizen, H. Biofuels and food security: Implications of an Accelerated Biofuels Production. Summary of the OFID Prepared by IIASA (International Institute for Applied Systems Analysis); OFID Pamphlet Series; The OPEC Fund for International Development: Vienna, Austria, 2009.

36. Binswanger, H. Brazilian Policies That Encourage Deforestation; Working Paper No. 16; Environment Department, World Bank: Washington, DC, USA, 1989.

37. Hecht, S. Environment, development and politics: Capital accumulation and the livestock sector in eastern Amazonia. World Dev. 1985, 13, 663-684.

38. Public Policies and the Misuse of Forest Resources; Repetto, R., Gillis, M., Eds.; A World Resources Institute Book; Cambridge University Press: Cambridge, UK, 1988.

39. Skutsch, M.; Masera, O.; Gao, Y. Policies that Moderate the Impacts of Biofuels on Deforestation, Draft; CIFOR and UNAM: Bogor, Indonesia, 2010.

40. Wertz-Kanounnikoff, S.; Angelsen, A. Global and national REDD+ architecture: Linking institutions and actions. In Realising REDD+: National Strategy and Policy Options; Angelsen, A.; Brockhaus, M., Kanninen, M., Sills, E., Sunderlin, W.D., Wertz-Kanounnikoff, S., Eds.; Center for International Forestry Research (CIFOR): Bogor, Indonesia, 2009; pp. 13-24.

41. Mitchell, C. New studies of political decentralization in Latin America. Latin Am. Res. Rev. 2006, 41, 175-184.

42. Larson, A.M.; Pacheco, P.; Toni, F.; Vallejo, M. Trends in Latin American forestry decentralisations: Legal frameworks, municipal governments and forest-dependent groups. Int. Forest. Rev. 2007, 9, 734-747.

43. Toni, F. Decentralisation and REDD+ in Brazil. Forests 2011, 2, 66-85.

44. Rayner, S. How to eat an elephant: A bottom-up approach to climate policy. Climate Policy 2010, 10, 615-621.

45. Cerbu, G.A.; Swallow, B.M.; Thompson, D.Y. Locating REDD: A global survey and analysis of REDD readiness and demonstration activities. Environ. Sci. Policy 2010, in press.

46. Agrawal, A.; Nelson, F.; Adams, W.M.; Sandbrook, C. Governance and REDD: A reply to Wunder. Oryx 2010, 44, 335-338.

47. Wunder, S. Forest decentralization for REDD? A response to Sandbrook et al. Oryx 2010, 44, 335-338.

48. Conyers D. Decentralization: The latest fashion in development administration? Public Administ. Dev. 1983, 3, 97-109. 
49. Larson, A.M. Formal decentralization and the imperative of decentralization 'from below': A case study of natural resource management in Nicaragua. In Democratic Decentralization through a Natural Resource Lens; Ribot, J.C., Larson, A.M., Eds; Routledge: London, UK, 2005.

50. Corbera, E.; Estrada, M.; May, P.; Navarro, G.; Pacheco, P. Rights to forests and carbon: Insights from Mexico, Brazil and Costa Rica. Presented at the Oaxaca Workshop on Forest Governance, Decentralization and REDD+ in Latin America and the Caribbean, A Country-Led Initiative in Support to UNFF by the Governments of Mexico and Switzerland, Oaxaca, 31 August-3 September 2010.

51. Barragán, L. Documento base preliminar del foro electrónico: pueblos indígenas y áreas protegidas en América Latina; Progress Report; Food and Agriculture Organization and Organismo Autónomo Parques Nacionales de España: Santiago, Chile. January 2007; Available online: http://www.rlc.fao.org/es/tecnica/ parques/pdf/DocBaseP.pdf (accessed on 1 July 2010).

52. van Dam, C. Indigenous territories and REDD in Latin America: Opportunity or threat? Presentation at the Oaxaca Workshop on Forest Governance, Decentralization and REDD+ in Latin America and the Caribbean, A Country-Led Initiative in Support to UNFF by the Governments of Mexico and Switzerland, Oaxaca, 31 August-3 September 2010.

53. Tropical Forest Tenure Assessment: Trends, Challenges and Opportunities; RRI: Washington, DC, USA; International Tropical Timber Organization: Yokohama, Japan, 2009.

54. Larson, A.M.; Barry, D.; Cronkleton, P.; Pacheco, P. Tenure Rights and Beyond: Community Access to Forest Resources in Latin America; CIFOR Occasional Paper 50; CIFOR: Bogor, Indonesia, 2008.

55. Forests for People: Community Rights and Forest Tenure Reform; Larson, A.M., Barry, D., Dahal, G.R., Colfer, C.J.P., Eds.; Earthscan: London, UK, 2010.

56. Larson, A.M.; Mendoza-Lewis, J. Desafíos en la Tenencia Comunitaria de Bosques en la Región Autónoma Atlántico Norte (RAAN) de Nicaragua; CIFOR/URACCAN: Managua, Nicaragua, 2009.

57. Monterroso, I.; Barry, D. Tenencia de la tierra, bosques y medios de vida en la reserva de la biosfera Maya en Guatemala: Sistema de concesiones forestales comunitarias; CIFOR/FLACSO, Editorial de Ciencias Sociales: Guatemala, 2009.

58. Cronkleton, P.; Pacheco, P.; Ibarguen, R.; Albornoz, M. Reformas en la tenencia de la tierra y los bosques: La gestión communal en las tierras bajas de Bolivia; CIFOR and CEDLA: La Paz, Bolivia, 2009.

59. Pacheco, P.; Nunes, W.; Rocha, C.; Vieira, I.; Herrera, J.; Alves, K.; Feitosa, T.; Cayres, G. Acesso à terra e meios de vida: examinando suas interações em três locais no Estado do Pará; CIFOR,LAET/NEAF/UFPA/ARCA: Santa Cruz, Bolivia, 2008.

60. Cotula, L.; Dyer, N.; Vermeulen, S. Fuelling Exclusion? The Biofuels Boom and Poor People's Access to Land; International Institute for Education and Development: London, UK, 2008.

61. Food and Agricultural Organization of the UN (FAO) National Forestry Monitoring and Assessment; FAO: Rome, Italy; Available online: http://www.fao.org/forestry/nfma/47655/en/ (accessed on 15 August 2010).

62. Quiroga, R.; Maluenda, J.; Castano, J. Mejoran las estadísticas forestales en Latinoamérica. OIMT Actual. Forest. Trop. 2003, 11, 13-15. 
63. Navarro, G.; Del Gatto, F.; Faurby, O.; Arguello, A. Verificación de la Legalidad en el Sector Forestal Nicaraguense. VI Congreso Forestal Centroamericano 'Competitividad, Sostenibilidad Forestal en Centroamérica', San Salvador, El Salvador, 29-31 August 2007.

64. Carvalheiro, K.; Sabogal, C.; Amaral, P. Análise da legislação para o manejo florestal por pequenos produtores na Amazônia Brasileira; Center for International Forestry Research (CIFOR): Belem, Pará, Brazil, 2008.

65. Silva, E.; Kaimowitz. D.; Bojanic, A.; Ekoko, F.; Manurung, T.; Pavez, I. Making the law of the jungle: The reform of forest legislation in Bolivia, Cameroon, Costa Rica, and Indonesia. Glob. Environ. Polit. 2002, 2, 63-97.

66. Larson, A.M.; Ribot, J. The poverty of forest policy: Double standards on an uneven playing field. Sustain. Sci. 2007, 2, 189-204.

67. Kolstad, I.; Soreide, T. Corruption in natural resource management: Implications for policy makers. Res. Policy 2009, 34, 214-226.

68. Contreras-Hermosilla, A. People, governance and forests: The stumbling blocks in forest governance reform. Presented at the Oaxaca Workshop on Forest Governance, Decentralization and REDD+ in Latin America and the Caribbean, A Country-Led Initiative in Support to UNFF by the Governments of Mexico and Switzerland, Oaxaca, 31 August-3 September 2010.

69. Elías, E. Autogestión comunitaria de recursos naturales. El caso de Totonicapán; FLACSO: Guatemala, 2007.

70. Elías, S.; Larson, A.; Mendoza, J. Tenencia de la tierra, Bosques y Medios de Vida en el Altiplano Occidental de Guatemala; CIFOR/FAUSAC: Guatemala, Guatemala, 2009.

71. Strengthening Forest Law Enforcement and Governance-Addressing a Systemic Constraint to Sustainable Development; World Bank: Washington, DC, USA, 2006.

72. Kaufmann, D. Misrule of Law: Does the Evidence Challenge Conventions in Judiciary and Legal Reforms? World Bank: Washington, DC, USA, 2001; Available online: http://siteresources.worldbank.org/INTWBIGOVANTCOR/Resources/misruleoflaw.pdf (accessed on 15 August 2010).

73. World Resources Report. The Wealth of the Poor: Managing Ecosystems to Fight Poverty; World Resources Institute: Washington, DC, USA, 2005.

74. Kaufmann, D.; Kraay, A.; Mastruzzi. M. Governance Matters VIII: Governance Indicators for 1996-2008; World Bank: Washington, DC, USA, 2009.

75. Brown, D.; Schreckenberg, K.; Bird, N.; Cerutti, P.; Del Gatto, F.; Diaw, C.; Fomete, T.; Luttrell, C.; Navarro, G.; Oberndorf, R. Legal Timber: Verification and Governance in the Forest Sector; Overseas Development Institute: London, UK, 2008.

76. Using Drivers of Change to Improve Aid Effectiveness; DFiD Practice paper; Department for International Development (DFID).: London, UK, 2005.

77. Crooke, B.; Kothari, U. Participation: The New Tyranny; Zed Books Ltd.: New York, NY, USA, 2004.

78. Durban Group for Climate Justice. No REDD! No REDD Plus. Global Sign-On Campaign against Schemes for Reducing Emissions from Deforestation and Forest Degradation. Durban Group for Climate Justice: Durban, South Africa, 13 April 2010; Available online: http://www.durbanclimatejustice.org (accessed on 10 September 2010). 
79. Environmental Justice in Latin America: Problems, Promise, and Practice; Carruthers, D., Ed.; Massachusetts Institute of Technology: Cambridge, MA, USA, 2008.

80. Saule, N.; Velasco, A.M.; Arashiro, Z. Legal Frameworks for Citizen Participation: Latin America Regional Report; LogoLink: University of Sussex: Brighton, UK, 2002; Available online: http://www.ids.ac.uk/logolink/resources/legalframeregional.htm (accessed on 15 August 2010).

81. Mendel, T. The Right to Information in Latin America: A Comparative Legal Survey; United Nations Educational, Scientific and Cultural Organization: Quito, Ecuador, 2009; Available online: http://unesdoc.unesco.org/images/0018/001832/183273e.pdf (accessed on 15 August 2010).

82. Access Initiative. Situation of Access to Environmental Information, participation and justice in Latin America, 2004-2005. Iniciativa de Acceso Mexico y Corporación Participa: Mexico and Chile, 2005; Available online: http://www.accessinitiative.org (accessed on 10 June 2010).

83. Avritzer, L. Democracy and the Public Space in Latin America; Princeton University Press: Princeton, NJ, USA, 2002.

84. Cuellar, N.; Kandel, S.; Davis, A.; Elizondo, D. El proceso de preparacion para REDD+en Mesoamerica; PRISMA: San Salvador and Grupo Cabal: Managua, Nicaragua, 2010.

85. Brandon, K.; Wells, M. Lessons for REDD+ from protected areas and integrated conservation and development projects. In Realising REDD+: National Strategy and Policy Options; Angelsen, A., Ed.; CIFOR: Bogor, Indonesia, 2009; pp. 225-236.

(C) 2011 by the authors; licensee MDPI, Basel, Switzerland. This article is an open access article distributed under the terms and conditions of the Creative Commons Attribution license (http://creativecommons.org/licenses/by/3.0/). 